\title{
Atomic Layer Deposition of Tungsten Oxide using Nitrogen Dioxide: A Comparative Study with Other Oxygen Sources
}

Damon B. Farmer ${ }^{\dagger *}$, Matthew Copel ${ }^{\dagger}$, Teodor Todorov ${ }^{\dagger}$, John A. Ott ${ }^{\dagger}$, Marinus Hopstaken ${ }^{\dagger}$, Holt Bui $^{\ddagger}$, Charles Tabachnick ${ }^{\dagger}$, Gloria Fraczak ${ }^{\dagger}$, George Totir ${ }^{\dagger}$

†IBM T.J. Watson Research Center, Yorktown Heights, New York 10598, United States IBM Almaden Research Center, San Jose, California 95110, United States

Supporting Information
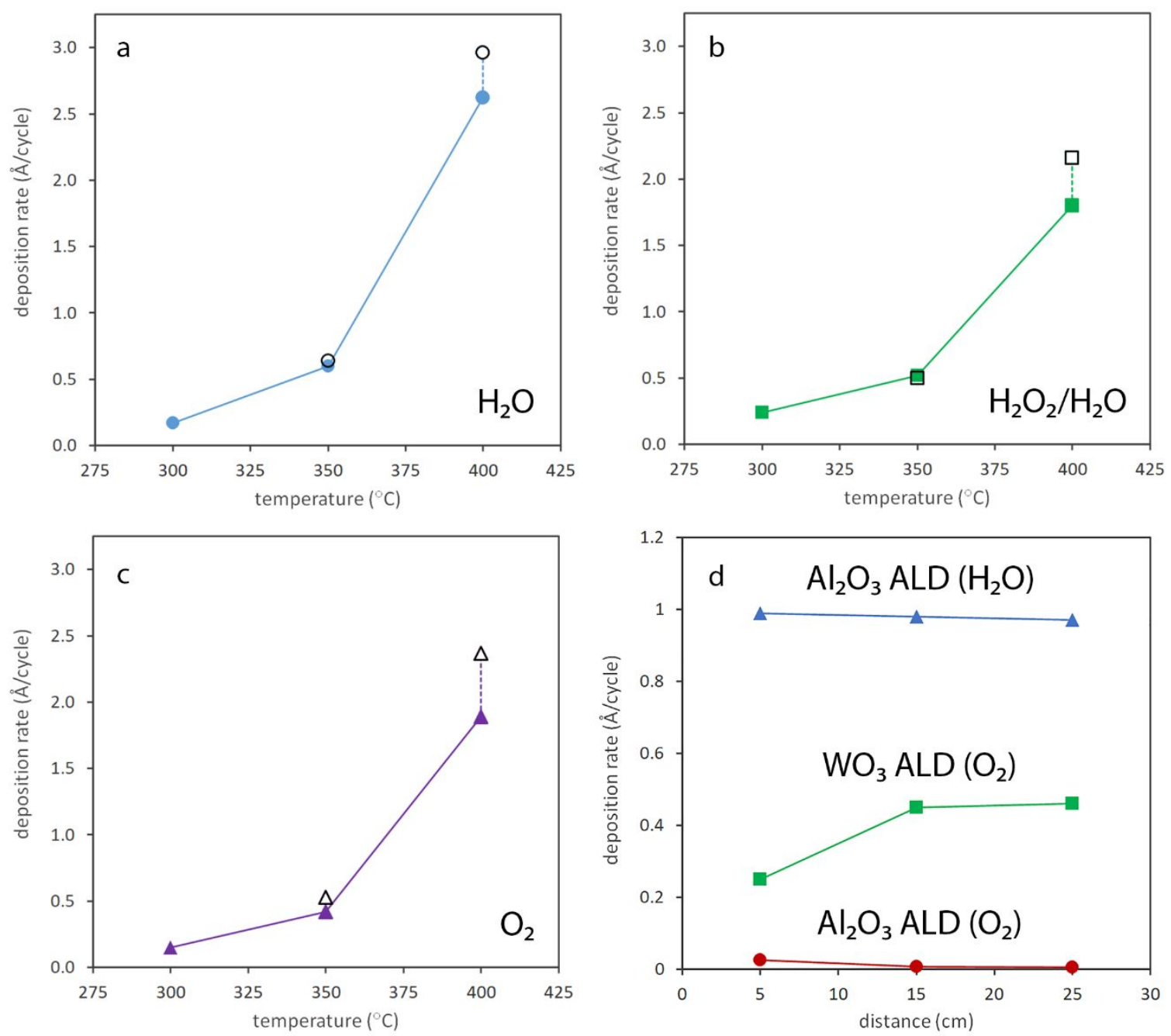

Figure S1. Ancillary experiments and ALD characterization. a-c) ALD deposition behavior and process optimization using $\mathrm{H}_{2} \mathrm{O}, \mathrm{H}_{2} \mathrm{O}_{2} / \mathrm{H}_{2} \mathrm{O}$, and $\mathrm{O}_{2}$ as the oxygen precursors. The colored, filled data points at $300^{\circ} \mathrm{C}$, $350^{\circ} \mathrm{C}$, and $400^{\circ} \mathrm{C}$ correspond to a $\left({ }^{\mathrm{t}} \mathrm{BuN}\right)_{2}\left(\mathrm{Me}_{2} \mathrm{~N}\right)_{2} \mathrm{~W}$ dose volume of $13.64 \mathrm{~mL}$. The black, open data points at $350^{\circ} \mathrm{C}$ and $400^{\circ} \mathrm{C}$ correspond to a dose volume of $20.46 \mathrm{~mL}$. d) Deposition rate dependence on position in the ALD reaction zone. The position at $5 \mathrm{~cm}$ roughly corresponds to the beginning of the heated reaction zone, closest to the precursor inlets. The position at $25 \mathrm{~cm}$ roughly corresponds to the end of the heated zone, closest to the vacuum assembly. 
In order to properly compare tungsten oxide ALD using $\mathrm{NO}_{2}$ with the other thermal oxygen sources it is necessary to establish ALD behavior and the optimal processing conditions required for each process. These results are shown in Fig. S1a-c. Here, the thin film deposition rate is determined for each process at $300^{\circ} \mathrm{C}, 350^{\circ} \mathrm{C}$, and $400^{\circ} \mathrm{C}$. In all cases, this rate increases with increasing temperature, from being prohibitively low at $300^{\circ} \mathrm{C}$ to relatively high at $400^{\circ} \mathrm{C}$. Furthermore, increasing the precursor dose volume by $50 \%$ reveals ALD behavior at $350^{\circ} \mathrm{C}$ and CVD behavior at $400^{\circ} \mathrm{C}$ for each precursor. At $350^{\circ} \mathrm{C}$, the deposition rates do not significantly change with the larger dose, indicating self-limiting deposition behavior. In contrast, this rate increases substantially at $400^{\circ} \mathrm{C}$, indicative of CVD.

It is worthwhile to investigate if deposition attained using the $\left({ }^{t} \mathrm{BuN}\right)_{2}\left(\mathrm{Me}_{2} \mathrm{~N}\right)_{2} \mathrm{~W}+\mathrm{O}_{2}$ process is indeed the result of $\mathrm{O}_{2}$ exposure or potentially due to residual water in the $\mathrm{O}_{2}$ source. The first indication that $\mathrm{O}_{2}$ is responsible for film deposition instead of $\mathrm{H}_{2} \mathrm{O}$ is from the fact that the properties of films processed with $\mathrm{O}_{2}$ and $\mathrm{H}_{2} \mathrm{O}$ are different, as outlined in the paper. So, the surface reactions and resulting film in the $\mathrm{O}_{2}$ case cannot solely be attributed to the presence of residual water. Deposition due to unwanted, residual water has been a concern in other ALD studies, such as L. Aarik, et al. Appl. Surface Sci. 530, 147229 (2020), where $\mathrm{HfO}_{2}$ was deposited using ozone. In this study, the contribution of residual water was investigated by only using the $\mathrm{O}_{2}$ source, without ozone generation. Unfortunately, we are unable to do something like this in the present study. We cannot directly decouple the contribution of any residual water in the $\mathrm{O}_{2}$ source from the $\mathrm{O}_{2}$ itself.

In an attempt to determine if there is water in the $\mathrm{O}_{2}$ source that significantly contributes to film deposition, ancillary studies have been performed using trimethylaluminum (TMA) instead of the $\left({ }^{\mathrm{t}} \mathrm{BuN}\right)_{2}\left(\mathrm{Me}_{2} \mathrm{~N}\right)_{2} \mathrm{~W}$ (Fig. S1d). The TMA $+\mathrm{H}_{2} \mathrm{O}$ ALD chemistry has been thoroughly studied for the deposition of aluminum oxide films over a relatively large temperature range. Instead of using $\mathrm{H}_{2} \mathrm{O}$, the $\mathrm{O}_{2}$ source was used in this process at $125^{\circ} \mathrm{C}$, effectively using TMA as a probe for residual water in the $\mathrm{O}_{2}$ source. This was done with the reasonable assumption that surface-reacted TMA does not react with $\mathrm{O}_{2}$ at this temperature. We found results similar to what L. Aarik, et al. found for $\mathrm{HfO}_{2}$ deposition from residual $\mathrm{H}_{2} \mathrm{O}$. There is a miniscule amount of aluminum oxide deposition nearest the precursor inlet, but essentially no deposition downstream of this point where the actual samples are processed. The ALD system was configured to allow for $\left({ }^{\mathrm{t}} \mathrm{BuN}\right)_{2}\left(\mathrm{Me}_{2} \mathrm{~N}\right)_{2} \mathrm{~W}$, TMA, $\mathrm{O}_{2}$, and $\mathrm{H}_{2} \mathrm{O}$ processing without disruption. Therefore, the TMA $+\mathrm{H}_{2} \mathrm{O}$ process at $125^{\circ} \mathrm{C}$ and the $\left({ }^{\mathrm{t}} \mathrm{BuN}\right)_{2}\left(\mathrm{Me}_{2} \mathrm{~N}\right)_{2} \mathrm{~W}+$ $\mathrm{O}_{2}$ process at $350^{\circ} \mathrm{C}$ could also be evaluated, where expected deposition rates were achieved for both. For the tungsten oxide case, the deposition rate is lower near the inlet. This is because the temperature in this area is slightly lower, and as has been presented in the present study reactivity of $\left({ }^{\mathrm{t}} \mathrm{BuN}\right)_{2}\left(\mathrm{Me}_{2} \mathrm{~N}\right)_{2} \mathrm{~W}$ is relatively sensitive to the process temperature. These results make it clear that surface-reacted TMA reacts with $\mathrm{H}_{2} \mathrm{O}$ but not with $\mathrm{O}_{2}$ at $125^{\circ} \mathrm{C}$, and that surface-reacted $\left({ }^{\mathrm{t}} \mathrm{BuN}\right)_{2}\left(\mathrm{Me}_{2} \mathrm{~N}\right)_{2} \mathrm{~W}$ reacts with $\mathrm{O}_{2}$ at $350^{\circ} \mathrm{C}$. Since little deposition was achieved when using the TMA $+\mathrm{O}_{2}$ process, it can be concluded that there is an insignificant amount of $\mathrm{H}_{2} \mathrm{O}$ in the $\mathrm{O}_{2}$ source, and that deposition of tungsten oxide with $\mathrm{O}_{2}$ is indeed due to reaction with the $\mathrm{O}_{2}$ itself and not with $\mathrm{H}_{2} \mathrm{O}$ residue. 